\title{
Young Communities and the Impact of Wars and Conflicts on the Healthy Growth of Young People: Middle East as a Model Study
}

\author{
Yaser Snoubar ${ }^{1}$
}

Tel. : +90 5068875044

yasersnober@hotmail.com

Hamed Hamed HAWAL

Tel. : +05425187991.

alihamed02@yahoo.com

Abstract

\begin{abstract}
Wars and armed conflicts throughout history is the most serious and the biggest factor on demographic changes of human societies, especially those that live in a state of constant conflict over different time periods or continuously. The world has witnessed many wars and conflicts that led to the deaths of millions of people, mostly children and youth. Despite the presence of many local and international agreements to protect the civilians in times of conflict and war, however it loses its effectiveness since the first day of the war. The society called Middle East, is one of societies that deserve special study. A society worthy of studying the impact of wars on it because from the beginning it has been a young society witnessing wars and conflicts continuously for decades. Despite the impact of the war on all segments of society, however, the young people deserve a special study since it is run by the conflict and are consequentially affected directly and indirectly in its sustainability. The young people are most likely to be killed, disabled, imprisoned or engaged in terrorist organizations, and militias. All of this in an atmosphere of instability and the absence of physical, psychological and social rehabilitation and the consequent chronic problems lead to improperly growth of the largest class in the society. This paper will address the impact of war and conflict on young people in the Middle East, including discussing topics of youth unemployment and participation in wars and conflicts and its impact on the healthy growth of the younger generation in the Middle East in general. In light of this study, there will be thrown many proposals that could contribute to the healthy growth of the younger generation within the Middle East region in the long term.
\end{abstract}

Keywords: wars and conflicts, the Middle East, young, young communities, psychological and social rehabilitation.

\section{Demographic Indicators in the Middle East Countries}

The Middle East countries is a region centered on Western Asia and Egypt. ( table 1) show that Egypt is the most populated country around 88.5 millions with $21.585 \%$ of all total, while Cyprus come in the end of this list as a less populated country 0.876 million with $0.21 \%$ of all total . Egypt, Iran and Turkey are the majority of population in the region 21. $58 \%, 19.21 \%$ and $19.07 \%$, respectively, representing combined more than $60 \%$ of all the over, while Iraq, Saudi Arabia, Yemen and Syria representing 8. 92\%, 7. 69\%, 6,52 and 5.67\%, respectively. While the rest of the countries range between $2 \%$ and less than $1 \%$ of all over .

Table 1: list of Middle Eastern countries and territories on the basis of population.

\begin{tabular}{|l|l|l|l|l|l|l|}
\hline Country & population & $\%$ of pop. & Annual growth \% & Absolute of annual growth & Estimated doubling time & Date \\
\hline Total & $\begin{array}{l}410,153,00 \\
0\end{array}$ & 100 & 2,09 & $8,411,000$ & 33 & \\
\hline
\end{tabular}

\footnotetext{
${ }^{1}$ 1Ph. D Student. Hacettepe University, Faculty of Economic and Administrative Sciences, Department of Social Work, "Ankara”, Turkey, 2M. Sc. Student Hacettepe University, Institute of Population Studies ,"Ankara”, Turkey, * Corresponding authors: Yaser Snoubar Tel. : +90 5068875044, E-mail address: yasersnober@hotmail. com Hamed Hamed HAWAL2, Tel. : +05425187991. E-mail address: alihamed02@yahoo. com
} 


\begin{tabular}{|c|c|c|c|c|c|c|}
\hline Egypt & $88,523,000$ & 21,58 & 2,29 & $1,981,000$ & 31 & \begin{tabular}{|l}
201 \\
5
\end{tabular} \\
\hline Iran & $78,778,000$ & 19,21 & 1,29 & $1,001,000$ & 54 & $\begin{array}{l}201 \\
5\end{array}$ \\
\hline Turkey & $78,214,000$ & 19,07 & 1,34 & $1,035,000$ & 52 & $\begin{array}{l}201 \\
4\end{array}$ \\
\hline Iraq & $36,575,000$ & 8,92 & 2,9 & $1,030,000$ & 24 & $\begin{array}{l}201 \\
5\end{array}$ \\
\hline $\begin{array}{r}\text { Saudi } \\
\text { Arabia }\end{array}$ & $31,521,000$ & 7,69 & 2,44 & 751 & 29 & $\begin{array}{l}201 \\
5\end{array}$ \\
\hline Yemen & $26,745,000$ & 6,52 & 2,95 & 766 & 24 & $\begin{array}{l}201 \\
3\end{array}$ \\
\hline Syria & $23,270,000$ & 5,67 & 2,45 & 557 & 29 & $\begin{array}{l}201 \\
1\end{array}$ \\
\hline UEA & $8,933,000$ & 2,18 & 1,57 & 138 & 45 & $\begin{array}{l}201 \\
0\end{array}$ \\
\hline Israel & $8,374,000$ & 2,04 & 1,89 & 155 & 37 & $\begin{array}{l}201 \\
5\end{array}$ \\
\hline Jordan & $6,837,000$ & 1,67 & 2,75 & 183 & 26 & $\begin{array}{l}201 \\
5\end{array}$ \\
\hline${ }_{]}^{\text {Palestine } e^{[5}}$ & $4,683,000$ & 1,14 & 2,92 & 133 & 24 & $\begin{array}{l}201 \\
4\end{array}$ \\
\hline Lebanon & $4,288,000$ & 1,05 & 1,78 & 75 & 39 & $\begin{array}{l}200 \\
7\end{array}$ \\
\hline Oman & $4,208,000$ & 1,03 & 5,2 & 208 & 14 & $\begin{array}{l}201 \\
5\end{array}$ \\
\hline Kuwait & $4,161,000$ & 1,01 & 3 & 121 & 23 & $\begin{array}{l}201 \\
4\end{array}$ \\
\hline Qatar & $2,386,000$ & 0,58 & 6,76 & 151 & 11 & $\begin{array}{l}201 \\
5\end{array}$ \\
\hline Bahrain & $1,781,000$ & 0,43 & 7,35 & 122 & 10 & $\begin{array}{l}201 \\
0\end{array}$ \\
\hline Cyprus & 876 & 0,21 & 0,46 & 4 & 151 & $\begin{array}{l}201 \\
2\end{array}$ \\
\hline
\end{tabular}

Source : http: //en. wikipedia. org/wiki/List_of_Middle_East_countries_by_population

On the other hand, the annual growth \% range between $7.35 \%$ for Bahrain to 1. 57\% for UEA if we excluded Cyprus with $0.46 \%$, it is easy to notice the High rate of growth, especially, in the Gulf states ; Bahrain, Qatar , Oman and Saudi Arabia as $7.35 \%, 6.76 \%, 5.2$ and 2.44 ,respectively, according to high growth rate the estimated doubling time running on the same mode , for example ; bahrain just need 10 years for doubling population , to be more than 3 millions by 2020. From the above ( table 1), it is obviously that the Middle East region with that high population growth rate will be reached one 
billion after a little decades, the Middle East is experiencing an unprecedented "youth bulge. ", for sure youth play an important role, for that the study will focus on youth.

\section{Demographic Indicators for Youth Ages 15 To 24 In Mena Countries}

The Middle East region one of the most accelerated growth population in the world, Where youth constitute the largest proportions "youth bulge. " With 20 percent of its population between the ages of 15 and 25 representing about 45 million youth, this is the highest proportion of youth to adults in the region's history.

TABLE 2. SELECTED DEMOGRAPHIC INDICATORS FOR YOUTH AGES 15 TO 24 IN MENA COUNTRIES

\begin{tabular}{|c|c|c|c|c|c|c|c|}
\hline \multirow{2}{*}{ Country } & $\begin{array}{l}\text { Youth } \\
1000 \text { s) }\end{array}$ & \multicolumn{2}{|c|}{ Population } & \multicolumn{2}{|c|}{$\begin{array}{l}\text { youth as } \mathrm{F} \\
\text { Population }\end{array}$} & Percent of tot & \multirow{2}{*}{$\begin{array}{l}\begin{array}{l}\text { youth as } \% \text { of working age } \\
\text { Population }\end{array} \\
2010\end{array}$} \\
\hline & 1980 & 2010 & 2040 & 1980 & 2010 & 2040 & \\
\hline Bahrain & 79 & 188 & 200 & 22 & 15 & 11 & 19 \\
\hline Egypt & 8,889 & 16,009 & 17,624 & 20 & 20 & 15 & 31 \\
\hline Iran & 7,648 & 16,253 & 9,559 & 20 & 22 & 11 & 31 \\
\hline Iraq & 2,495 & 6,205 & 12,817 & 18 & 20 & 19 & 37 \\
\hline Jordan & 448 & 1,332 & 1,463 & 20 & 22 & 16 & 37 \\
\hline Kuwait & 246 & 423 & 552 & 18 & 16 & 12 & 22 \\
\hline Lebanon & 569 & 759 & 580 & 20 & 18 & 12 & 26 \\
\hline Libya & 558 & 1,124 & 1,171 & 18 & 18 & 14 & 27 \\
\hline Oman & 208 & 611 & 448 & 18 & 22 & 12 & 31 \\
\hline $\begin{array}{l}\text { Palestinian } \\
\text { Terr. }\end{array}$ & 289 & 858 & 1,544 & 19 & 21 & 19 & 39 \\
\hline Qatar & 45 & 256 & 264 & 20 & 15 & 11 & 17 \\
\hline Saudia Arabia & 1,743 & 4,947 & 6,032 & 18 & 18 & 14 & 27 \\
\hline Syria & 1,748 & 4,166 & 4,747 & 20 & 20 & 15 & 35 \\
\hline Turkey & 8,919 & 12,883 & 11,559 & 20 & 18 & 13 & 26 \\
\hline UEA & 185 & 1,211 & 1,052 & 18 & 16 & 9 & 20 \\
\hline Yemen & 1,524 & 5,327 & 9,955 & 19 & 22 & 19 & 42 \\
\hline Toatal MENA & 35,593 & 75,552 & 79,567 & 19. 3 & 18.9 & 13.9 & 29. 19 \\
\hline
\end{tabular}

Source: United Nations Population Division, World Population Prospects, the 2010 Revision.

(Table2) shows that many countries in the region have reached the highest percentage of their youth bulge, . Youth (aged 15-25) as a proportion of the total population ranges from $15 \%$ in Bahrai and Qatar , to $22 \%$ in Iran , Oman and Yemen, and the most populated country in the region Egypt are $20 \%$ and Syria share the same percent, Turkey, Saudi Arabia, libya and Libanon share same percent $18 \%$. by 2040 most youth proportion of the population of Middle East countries will decline. UEA will be at the least order between the countries in the region with $9 \%$, while Iraq, Yemen and Palestine will be $19 \%$, and the most populated countries in the region Egypt, Iran , and Turkey will drop ; $20 \%$ to $15 \%, 22 \%$ to $11 \%$, and $18 \%$ to $13 \%$, respectively . 
(Figure 1) shows that the Gulf states will be greatly reduced, leading to the decline of the phenomenon of "youth bulge. " , as Oman will drop $22 \%$ in 2010 to $12 \%$ by 2040 , also UEA will drop $16 \%$ in 2010 to $9 \%$ by 2040 . Average of MENA will drop from $18.9 \% 2010$ to $13.9 \%$ by 2040 , which means that the decline of the phenomenon of "youth bulge. " in the middle east countries .

Figure 1: Youth As Percent Of Total Population, AGES 15 TO 24 IN MENA COUNTRIES

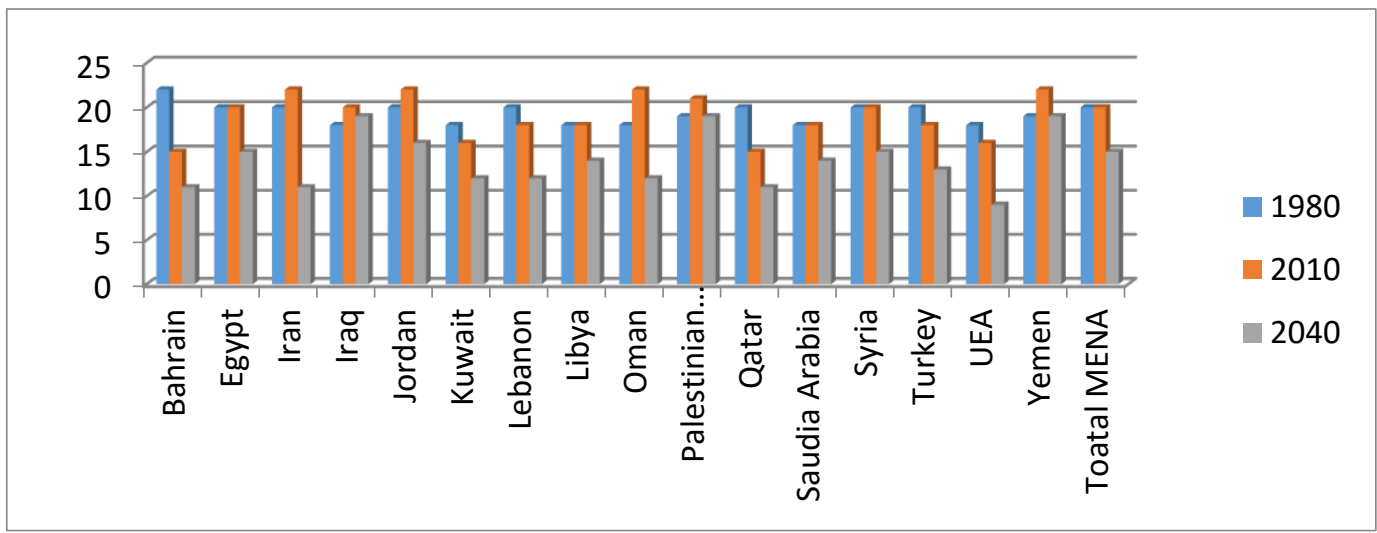

Source: United Nations Population Division, World Population Prospects, the 2010 Revision.

The mean of youth as percentage of working age population is around 30 percent, and it is noticeable that the highest youth as percentage of working age Population are the same countries which has seen wars and loss of security at the moment (table1) as ; Egypt , Syria, Iraq, Palestine, and Yemen are 31\%, 35\%, 37\%, 39\% , and $42 \%$, respectively . The economies of MENA countries would be booming if a high percentage of youth both males and females had the opportunity to move into gainful employment. But a significant portion of young people face high rates of unemployment and low wages (Roudi, 2011).

\section{Conflicts in the Middle East and the participation of young people}

The youth bulge in the Middle East plays a major role in the conflicts and instability through direct and indirect participation of youth. Unemployment and loss of employment due to wars and conflicts as well as the lack of youth-oriented services shape fertile ground for young people within the Middle East to participate in the ongoing conflicts.

There is a strong correlation between countries prone to civil conflicts and those with burgeoning youth populations. Some analyses have demonstrated that countries with a youth bulge (proportion of the adult population ages 15 to 29) of 41 percent or greater are at high risk of civil conflict. The vast majority of new civil conflicts in recent decades have occurred in countries in which at least 60 percent of the entire population is comprised of youth (ages 0 to 29) (Madsen et al, 2007). In one study based on interviews with young soldiers show that poverty, lack of schooling and low alternative income opportunities are risk factors and important reasons for participating in conflict with militant groups (Brett \& Specht, 2004). In short, we can say that the participation of young people in the Middle East conflicts have firmly rooted in the lack of social policies for the protecting young people throughout the period prior to revolutions.

\section{Youth problems in war and conflict area}

Since the youth is the most effective part in the conflict environment, they are the most vulnerable to psychological, social, physical and economic problems and exploitation by the militant fighters. Participation in the war means death, disability, prison, psychological and social problems, unemployment and dropping out of education and delay in marriage and family configure. These are the main problems faced by young people in armed conflicts and wars environment. As follows, we will discuss these problems individually to enable us to identify clearly the problems of young people in the communities of the conflict. 


\section{Death or Murder :}

In view of the roots of this problem, we find that history extends to the advent of colonialism to the Middle East for control of resources, sparking the diet of young people to defend their country, they were the first fighter rows which make them susceptible to direct injury and killing in large numbers, for example, current happenings in Palestine and Iraq. In addition Gates at el (2010) young men in particular are more likely to demonstrate against repressive governments .

In addition, the increase of inflation in the number of young people led to the aggravation of the conflict, which has affected the increase in the number of deaths of young people. The community of the Middle East, young and fertile floor of the conflict. Madsen et al (2007) that 80 percent of civil conflicts (defined as causing at least 25 deaths) occurred in countries in which 60 percent or more of the population is under age 30 , it is another thing altogether to prove statistically that the youthfulness of the population is a cause of civil conflict.

In short, we can say that the youth bulge in the Middle East led to the increase in the number of deaths among young people after the Arab spring and the outbreak of the civil wars in many countries through active participation in the rebellion against the ruling power and involvement in the ranks of the militant fighters.

\section{Detention:}

Detentions among young people and the accompanying prison for many years and death sentences in some countries due to the participation of youth in disputes acts had breached in governance systems in many Middle East countries, being one of the most important problems generated by the war and conflict .As well as the high prison sentences for many years and arbitrary judgments of thousands of young Palestinians as a result of their resistance to the Israeli occupation over the years extended its roots to 1948, is a clear example of the psychological, physical and social violence faced by young people as a result of their participation in the ongoing conflicts. It should be noted that the prison has an impact on young people from psychological, social and physical terms. Where the solitary confinement, torture, sexual harassment is considered risks faced by children and young people in prison in the war and conflict environment in the absence of human rights and monitoring. To view the harassment where the children and young people suffering in prisons; the following table contains a study of 100 Palestinian children in Israeli jails. This study presented the most important harassment of children and young people in prison.

Table 3. Analysis of 100 interviews of Palestinian children detained in Israeli prisons concerning torture (Quzmar: 2012, 2-4):

\begin{tabular}{|l|l|l|}
\hline Type of torture & Number (out of 100 cases) & Percentage \\
\hline Binding of the hands & 97 & $\% 97$ \\
\hline Blindfolding of the eyes & 92 & $\% 92$ \\
\hline Beating & 69 & $\% 69$ \\
\hline Detention after midnight & 65 & $\% 65$ \\
\hline Verbal abuse & 50 & $\% 50$ \\
\hline Threat & 49 & $\% 49$ \\
\hline $\begin{array}{l}\text { Signing of a confession in the Hebrew } \\
\text { language }\end{array}$ & 32 & $\% 32$ \\
\hline $\begin{array}{l}\text { keeping detainees in stress positions } \\
\text { for prolonged periods }\end{array}$ & 26 & $\% 26$ \\
\hline Solitary confinement & 14 & $\% 14$ \\
\hline
\end{tabular}




\begin{tabular}{|l|l|l|}
\hline Threat of sexual abuse & 12 & $\% 12$ \\
\hline Sexual abuse & 4 & $\% 4$ \\
\hline
\end{tabular}

As the counsellors explained, as a consequence of the traumatic experience of detention, child ex-detainees have developed a syndrome that is defined as Post Traumatic Stress Disorder [hereinafter PTSD] . Hence, on the emotional level, child ex-detainees reported being haunted by the frightening moments they experienced while in detention, especially having nightmares which lead many to wetting their beds. Other manifest symptoms reported include increased levels of fear, agitation, frustration, sadness, lethargic, and depression, low self esteem, anger, accompanied by hostile and aggressive behaviour towards others or themselves. Due to being imprisoned, child ex detainees feel insecure, communicate less, and resort to isolation due to a lack of sufficient coping mechanisms to overcome the high level of psycho-social difficulties they have experienced (SCS: 2008, 11).

In general it can be said that children's exposure to prison in conflict environment affects the psychological, social and physical development in the absence of rehabilitation and the continuation of violent events and live in a violent environment. Thus, the participation of young people in conflict within the Middle East can be traced easily to traumatic experiences in detention, whether in childhood or in young adulthood .

\section{Disability}

War led to the increase in the ratio of disability in community conflict inside the Middle East in general and among young people in particular. Disabilities resulting from the war are the most dangerous of the suffering of youth in the Middle East because of poverty, lack of physical and mental health and rehabilitative services. The continuation of the armed conflict has led to a crisis treatment on the local hospitals, and medicines interruption has also led to the aggravation of many injuries that led to permanent paralysis or temporary disability.

\section{Education}

There is no doubt that most of the Middle East countries suffer from enrollment in higher education problem where the youth bulge and lack of educational institutions and the low quality of educational material led to the creation of a gap in this area and a negative impact on the healthy growth of young people. In addition, the ongoing wars and conflicts have exacerbated the problem and the destruction of educational institutions targeted by artillery fire in many countries this led to depriving millions of children and young people of their right to education. As a result of the prison and disability, asylum and unemployment and poverty exacerbated by conflicts within the Middle East, many young people have not the ability to pursue higher education.

\section{Unemployment}

Despite young people's a product of social, economic and cultural structure where they live, in the same time the most conflict with this structure. Young people have always been pioneers of change progress (Karataş, 2001). Poor economic performance may be far more likely to lead to conflict when significant numbers of youth, particularly unemployed young men, are present (WDR, 2011).

Unemployment, poverty and inequality are considered the main features of the economic situation of many Middle Eastern countries especially among the young and accumulated this phenomenon with internal conflicts. As unemployment among young people has grown since the beginning of the war, it also was one of the most prominent reasons why young people are involved in conflicts and terrorist organizations and militias within the Middle East. ILO statistics in Table 4 for 2015 has shown that there is a marked increase in unemployment among young people in the Middle East. Clear to us through these statistics that the synchronized increase with the onset of the civil war in many countries.

Table 4: Youth unemployment rate in Middle East

\begin{tabular}{|l|l|l|l|l|l|l|l|l|l|}
\hline & 2009 & 2012 & 2013 & 2014 & 2015 & 2016 & 2017 & 2018 & 2019 \\
\hline Youth unemployment rate & 24.0 & 28.7 & 29.1 & 29.5 & 29.8 & 29.9 & 29.9 & 29.9 & 29.9 \\
\hline
\end{tabular}


Source: World employment and social outlook: Trends 2015 / International Labour Office. - Geneva: ILO, 2015

\section{Middle East Youth Involvement in Rebel Movements, Terrorist Organizations, Militias and Revolutions}

There is statistical evidence of a link between high relative youth populations and an increased risk of armed conflict. Structural models which forecast these risks combined with early-warning systems that monitor known trigger factors (such as youth unemployment and educational reversals) can therefore help identify countries with higher and lower risks of violence. A key factor driving youth involvement in violence is the structural exclusion and lack of opportunities faced by young people, which block or prolong their transition to adulthood and can lead to frustration, disillusionment and, in some cases, their participation violence. The principle "structural" factors that underlie youth exclusion are: (a) un- and underemployment and lack of livelihood opportunities; (b) insufficient, unequal and inappropriate education and skills; (c) poor governance and weak political participation; (d) gender inequalities and socialization; (e) a legacy of past violence. One quarter of young people in the Middle East are unemployed and unlikely to be able to afford housing, access credit, get married or start a family. The root cause of this youth exclusion lies in the rigid institutions and social norms that mediate transitions from school to work and family formation interconnected markets such as education, labour, housing and marriage. This stalled transition to adulthood has become known as waithood and fosters widespread frustration and discontent among young people (Hilker \& Fraser 2009). In short, the economic crises and widespread unemployment, lack of education and government neglect of the role of young people in the Middle East countries over the long years are the important factors that prompted the youth to participate in revolutions. Consequently, young people join organizations and militias which run the conflict and making them susceptible to the killing and torture, disability and unemployment.

\section{Social services and the healthy growth of young people}

In order for a healthy growth of young people and to avoid instability and violence in particular, focus should be on monitoring economic opportunities for young people, and particularly on providing employment or educational opportunities for youth in periods of economic decline. While expanding opportunities for education generally pacify youth cohorts, some evidence suggest that as opportunities for higher education is expanded, lack of employment opportunities for highly educated youth may contribute to instability (Urdal, 2011).

The majority of the Middle East countries lack for proper social policy for the protection of youth and their growth, and it shows in the lack of planning for the Youth social Services, educational, and economic. Despite the lack of such services, but the NGOs have played an important role for years in providing social services for youth through youth centers and provision of anti-unemployment, awareness and organization programs. Therefore, it is necessary to draw a social policy designed to protect youth by offering social services, organized in cooperation between civil domestic and international institutions operating within the Middle East, in the absence of the role of the state or government institutions that marginalized the youth and their role over the past decades.

For the healthy growth of the youth, we have to find the cultural institutions that will prepare a fertile ground for the growth of the intellectual and cultural youth through social and cultural services. Youth centers and sports events consider as services that will contribute to spend leisure among youth, thus contributing in the proper Growth. In short, it can be said that social services should be provided for youth for proper upbringing and protection that they might not be victims of conflicts and wars, simply, can be summarized that health and education services, social security, employment and the provision of financial resources will contribute in the assessment of leisure and integration in the cultural and social life, these measures will keep youth away from violence and conflicts.

\section{Discussion and suggestions}

Middle East is experiencing a great growth (youth bulge),in general, for decades the youth were marginalized by most Middle East countries, and did not find them a place in the fragile social policy. This marginalization of (youth bulge ) is no longer beneficial to a lot of countries and shows resentment of their economic and life conditions through the revolutions that took place in many countries, it was a time bomb so to speak. Where the participation of youth in the Arab Spring was as a result of a fledgling stressful environment that wiped out the ambition of youth by their drawbacks of the economic crisis and the subsequent of poverty, unemployment and fragile education system and the lack of youth participation policies. In addition, the occupation and its wars sparked in the region , where a harmful aspects for the youth, including 
the resulting of destructive aspects of life in general, and youth was a direct target . The result was a large number of deaths , injuries , disabilities, imprisonment, increasing unemployment and participation in the military actions and militants.

That any initiative to create a youth-conscious generation, in the shadow of war and conflict are considered useless, because peace is the environment that creates fertile ground for a proper generation. Since the non-governmental local and international institutions play a significant role in working with youth during times of crisis, we must have programs to raise awareness and move towards a democratic culture that has respect for human rights, freedoms, equality , the idea of justice, participation and consultation. Youth in most Middle East countries were deprived of these rights.

\section{References}

[1] Brett, R and Irma, S (2004) Young Soldiers: Why They Choose to Fight. Boulder, CO and London: Lynne Rienner.

[2] Farzaneh Roudi , Youth Population And Employment In The Middle East And North Africa: Opportunity Or Challenge?, (Washington, DC: Population Reference Bureau, 2011.

[3] Gates, S. , Hegre, H. , Nyga ${ }^{\circ}$ rd, H. M. , \& Strand, H. (2010). Consequences of armed conflict. Background paper for the 2011 World Development Report.

[4] Hilker, L. M. , Fraser E. M. (2009), 'Youth Exclusion, Violence, Conflict and Fragile States', Report prepared for DFID by Social Development Direct, London

[5] Karataş, Kasım "Barriers to Development: Unemployment and Youth Unemployment" Social Work Symposium'99 Social Work in Process of Regional Development, Ed. Ümit Onat and Aycan Altay, 75-88, Hacettepe University School of Social Work Publication No . : 007, Ankara, 2001.

[6] Madsen, E. , L. , Engelman, R. , Gibb Vogel, C. , Haddock, S. and Preston, T. (2007) The shape of things to come: why age structure matters to a safer, more equitable world. Washington, DC, Population Action International.

[7] QUZMAR, K (2012) The detention conditions of palestinian children, women, and sick persons detained in Israeli prisons. The question of Palestinian political prisoners in Israeli prisons and detention facilities: legal and political implications. Unıted Natıons Internatıonal Meetıng On The Questıon Of Palestıne Presented at the United Nations Conference Geneva, 3 and 4 April.

[8] SAVE THE CHILDREN SWEDEN (SCS). (2008) The Social Rehabilitation of Palestinian Child Ex-Detainees: A Long Run to Freedom A report to assess Palestinian children's needs and rights after detention, Jerusalem

[9] Wikipedia : http: //en. wikipedia. org/wiki/List_of_Middle_East_countries_by_population

[10] World Development Report Overview, "Conflict, security, and Development", World Bank, April 2011, and Regional study on Conflict, Fragility, and development, ,"Reducing Conflict Risk: conflict, security, and development in the Middle East and North Africa", World Bank, expected October 2011.

[11] World employment and social outlook: Trends 2015 / International Labour Office. - Geneva: ILO, 2015

[12] United Nations Population Division. World Population Prospects: The 2010 Revision (New York: UN, 2011).

[13] Urdal, H. 2011. A clash of generations? Youth bulges and political violence. Paper presented at the United Nations expert group meeting on adolescents, youth and development, 21-22 July, New York. 